\title{
Traffic Impact Study at the Existing Road Connecting between Botanical Garden of Gachibowli Miyapur Road and Ends at Prof C.R. Road, Hyderabad-Telangana
}

\author{
Koudagani Venkatesh ${ }^{1}$, Ratod Vinod Kumar ${ }^{2}$ \\ ${ }^{1,2}$ Assistant professors of Malla Reddy Institute of Technology \& Science, Maisammaguda,Dulapally, RangaReddy, tS500100
}

\begin{abstract}
The existing road network system in Hyderabad is facing lot of problems associated with inadequate traffic management and lack of efficient transport system. This has resulted inconsiderable growth and use of personalized vehicles leading to traffic congestions due to inadequate road configurations. The primary and secondary road network of GHMC consisting of arterial, sub arterial, collector and local streets under GHMC undergoing frequent maintenance due to frequent digging of roads along and across for laying of new/shifting of existing utilities, inadequate carriageway width for the ever growing vehicular traffic. there is more probability of accidents due to unavailability of median, warning signs etc. Apart from the above improper/lack of footpath for the vulnerable pedestrians, indiscriminate disposal of garbage and dumping of debris on the road side, unauthorized encroachments leading to reduction in road space thereby congestion, early failure of BT surface due to inadequate drainage facilities coupled with absence of proper camber, clogging of drains, quality of construction and maintenance etc., leading to the failure of these roads. Currently the existing road connecting between Botanical garden of Gachibowli Miyapur road and ends at prof C.R. Road .the Road is very narrow and frequent traffic jams occur on this road leading to inordinate delay for traffic. Most of the traffic passing through this road is two wheelers, cars, light commercial vehicles etc. there is a lot of open space In some areas along the road. and there is a little space for widening due to the establishments such as commercial shops, religious structures etc., very close to the road in some areas along the road
\end{abstract}

Keywords: Design pavement composition, periodic repair costing, provision of dowel bar \& tie bar, design of junctions, cost comparison

\section{Introduction: Requirements for Good Pavement}

Satisfactory pavement performance depends upon the proper design and functioning of all of the key components of the pavement system. These include:

- A wearing surface that provides sufficient smoothness, friction resistance, and sealing or drainage of surface water

- Bound structural layers (i.e., asphalt or Portland cement concrete) that provide sufficient load-carrying capacity, as well as barriers to water intrusion into the underlying unbound materials.

- Sufficient thickness to distribute the wheel load stresses to a safe value on the sub grade soil

- Long design life with low maintenance cost

- A subgrade that provides a uniform and sufficiently stiff, strong, and stable foundation for the overlying layers.
- Drainage systems that quickly remove water from the pavement system before the water degrades the properties of the unbound layers and sub grade.

- Produce least noise from moving vehicles

- Dust proof surface so that traffic safety is not impaired by reducing visibility

Traditionally, these design issues are divided among many groups within an agency. The geotechnical group is typically responsible for characterizing the foundation characteristics of the subgrade. The materials group may be responsible for designing a suitable asphalt or Portland cement concrete mix and unbound aggregate blend for use as base course. The pavement group may be responsible for the structural ("thickness") design. The construction group may be responsible for ensuring that the pavement structure is constructed as designed.

\section{An Index Map Showing the Road Alignment are Given Below}




\section{International Journal of Science and Research (IJSR) \\ ISSN (Online): 2319-7064}

Index Copernicus Value (2013): 6.14 | Impact Factor (2015): 6.391

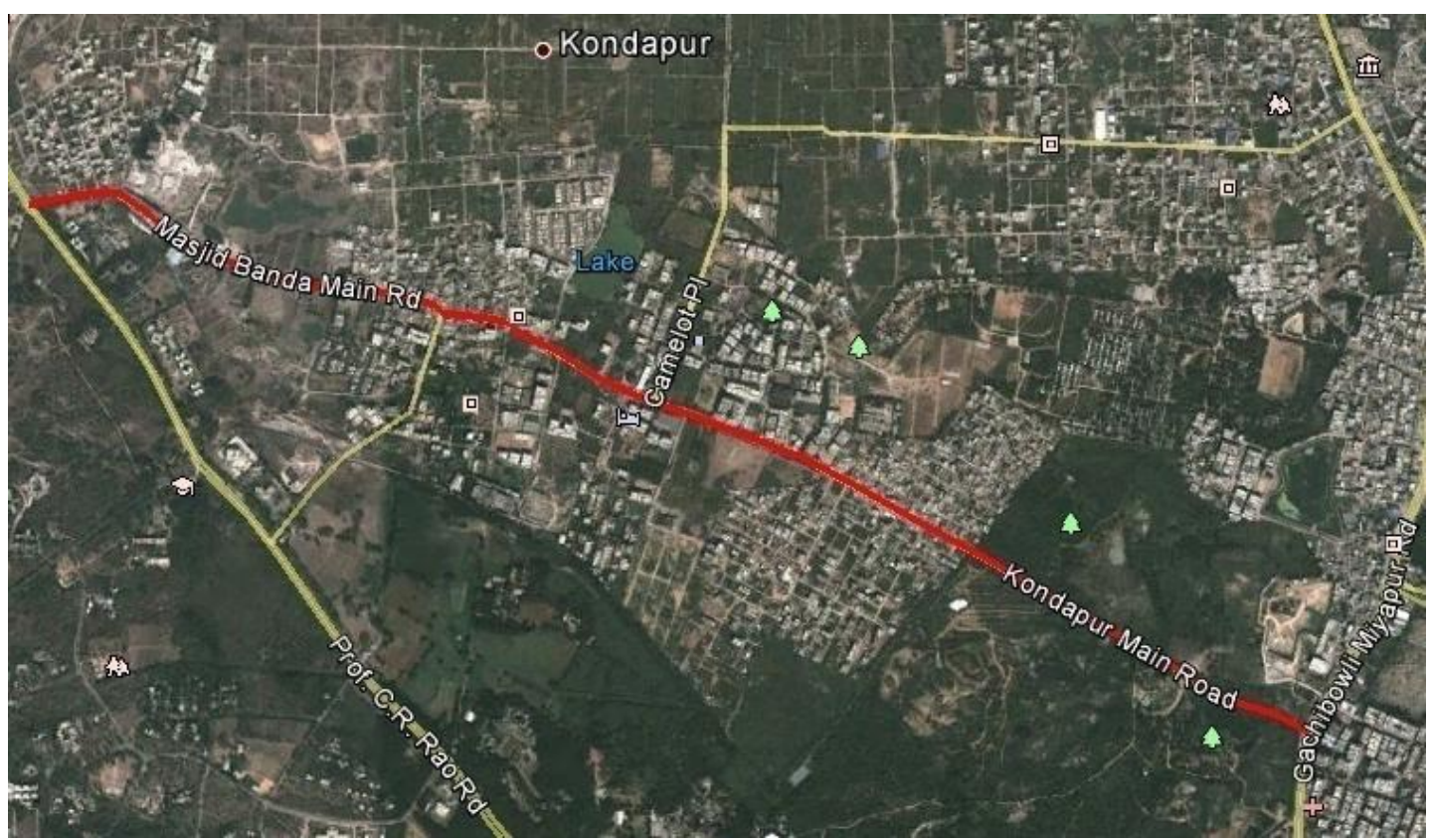

Figure: An Index Map Showing the Project Road Alignment

\section{Design of Flexible Pavement (Widening/Reconstruction)}

The traffic loading over design life period in terms of cumulative number of standard axles on the project road section would be calculated based on the following formula. $\left.\mathrm{N}=365 \times\left[(1+\mathrm{r})^{\wedge} \mathrm{n}-1\right)\right] \times \mathrm{A} \times \mathrm{D} \times \mathrm{F} / \mathrm{r}$

Where,

$\mathrm{N}$ = Cumulative number of standard axles to be catered in the design in terms of MSA

A = Initial traffic in the year of completion of construction in terms of number of Commercial Vehicles per Day.

$\mathrm{D}=$ Lane Distribution Factor, $\mathrm{F}=$ Vehicle Damage Factor.

$\mathrm{n}=$ Design Life in Years, $\mathrm{r}=$ Annual Growth Rate of Commercial Vehicles (For 7.5\%, $\mathrm{R}=0.075$ )

\section{Design Pavement Composition}

Mainline Pavement:

Traffic Loading - 22.9 msa

Design CBR - $10 \%$

Asphalt Concrete (AC) - $40 \mathrm{~mm}$

Dense Bituminous Macadam (DBM) - 100 mm

Wet Mix Macadam (WMM) - $250 \mathrm{~mm}$

Granular Sub-base - $200 \mathrm{~mm}$

Cycle Track Paving

RMC M20 Concrete - 15mm

Wet Mix Macadam (WMM) - 250 mm

\section{Strengthening Of Existing Carriageway}

The design life considered for the overlays is 10 years. The design traffic loading is estimated for the design life works out to 7.6 msa. It is proposed to strengthen the existing carriageway by means of bituminous overlays.

\section{Overlay Thickness}

Asphalt Concrete $-40 \mathrm{~mm}$
Dense Bituminous Macadam -50 mm

\section{Surface Treatment}

Before application of profile correction and overlays, existing bituminous surface needs treatment. The proposed surface treatment to existing pavement depends upon extent of distress, which was observed during condition surveys. This includes pothole (deep) filling with coarse aggregate base and Bituminous Macadam, crack sealing using slurry seal etc. The highly distressed pavement with patches, shallow potholes, ravelling, rutting and extensive cracking is refilled with Bituminous Macadam. Bituminous material after reconditioning may be used for the purpose along with new material after checking the suitability.

\section{Structural Overlay Costing of Flexible Pavement}

\begin{tabular}{|c|c|c|c|c|c|c|}
\hline Overlay Crust & Cost/km & No & $\begin{array}{c}\text { Length } \\
(\mathrm{m})\end{array}$ & $\begin{array}{c}\text { Thickness } \\
(\mathrm{m})\end{array}$ & $\begin{array}{c}\text { Width } \\
(\mathrm{m})\end{array}$ & Rate (Rs) \\
\hline $\begin{array}{c}\text { Bituminous } \\
\text { Concrete (BC) }\end{array}$ & $3,464,706$ & 1 & 1000 & 0.040 & 10.5 & $8,249.30$ \\
\hline $\begin{array}{c}\text { Dense } \\
\text { Bituminous } \\
\text { Macadam } \\
\text { (DBM) }\end{array}$ & $3,994,883$ & 1 & 1000 & 0.050 & 10.5 & $7,609.30$ \\
\hline $\begin{array}{c}\text { Profile } \\
\text { Correction } \\
\text { Course (BM) }\end{array}$ & $2,927,400$ & 1 & 1000 & 0.050 & 10.5 & $5,576.00$ \\
\hline Tack Coat & 396,270 & 3 & 1000 & - & 10.5 & 12.58 \\
\hline Initial Cost & $\mathbf{1 0 , 7 8 3 , 2 5 9}$ & & & & & \\
\hline
\end{tabular}

\section{Periodic Repair Costing}

The following Pot Hole Progression model developed by Central Road Research Institute (CRRI) was been made use of:

$$
\% \text { Pot Hole }=\frac{1.23 \times \% \mathrm{CP} \times \text { MSA } \times(1+\mathrm{CQ})}{170 \times \mathrm{MSN}}+(2.5 \times \% \text { PI } \times \text { MSA } \times(1+\mathrm{CQ}))
$$

Where,

$$
\% \mathrm{CP}=\text { Percentage Cracking }=4.26 \times(\mathrm{CMSA} / \mathrm{MSN}) \mathrm{X} 0.56 \times(\mathrm{SCRi})^{0.32}
$$




\section{International Journal of Science and Research (IJSR) \\ ISSN (Online): 2319-7064 \\ Index Copernicus Value (2013): 6.14 | Impact Factor (2015): 6.391}

$\%$ PI = Percentage Pot Holes Initiated $=0.13 \times\left(170^{0.47}\right) \times \mathrm{e}$ $0.12 \times$ MSA

MSA $=$ Standard Axles in Million, CMSA= Cumulative

Standard Axles in Million

MSN = Modified Structural Number $=3.28$ x (Initial

Deflection $)^{-0.23}$

$\mathrm{CQ}=$ Construction Quality= 0 for Major Roadways

$=1$ for Minor Roadways

$\mathrm{SCRi}=$ Percent Surfacing Cracking Initiated $=4$

$1.09 *(\mathrm{CMSA} / \mathrm{MSN} \wedge 2)$

\section{Design of Rigid Pavement}

From Geotechnical investigations, it was observed that the existing sub grade / natural ground soaked CBRs is varies from $6 \%$ to $15 \%$. However, the design of concrete pavement is based on $10 \%$ sub grade CBR.

\section{Design Input}

\begin{tabular}{|ll|}
\hline Tire wheel pressure & $=8 \mathrm{~kg} / \mathrm{cm} 2$ \\
\hline Design life & $=30$ Years \\
Elasticity of Concrete, E & $=300000 \mathrm{~kg} / \mathrm{cm}^{2}$ \\
\hline Poisson's ratio of concrete, $\mu$ & $=0.15$ \\
\hline Temperature differentials, $\mathrm{t}$ & $=21^{\circ} \mathrm{C}$ \\
\hline $\begin{array}{l}\text { Co-efficient of linear expansion of concrete, } \\
\propto\end{array}$ & $=0.00001 /{ }^{\circ} \mathrm{C}$ \\
\hline Load safety factor (LSF) & $=1.2$ \\
\hline Flexural strength of concrete, fck & $=45 \mathrm{~kg} / \mathrm{cm}^{2}$ \\
\hline Coefficient of friction, $\mathrm{f}$ & $=1.5$ \\
\hline Density of concrete, $w$ & $=2400 \mathrm{~kg} / \mathrm{m}^{3}$ \\
\hline
\end{tabular}

Permissible Tensile stresses in Plain bars, fls $=1250 \mathrm{~kg} / \mathrm{cm}^{2}$ Permissible Tensile stresses in deformed $\quad=2000 \mathrm{~kg} / \mathrm{cm}^{2}$ bars, shs

Permissible bearing stress in concrete, bes $=100 \mathrm{~kg} / \mathrm{cm}^{2}$ Permissible bond stress in plain tie bars, bop $=17.5 \mathrm{~kg} / \mathrm{cm}^{2}$ Permissible bond stress in deformed tie bars, $=24.6 \mathrm{~kg} / \mathrm{cm}^{2}$ bod

$\mathbf{k}$ value comes out to be $4.5 \mathrm{~kg} / \mathrm{cm} 2 / \mathrm{cm}$. IRC 15:2002 suggests that cement concrete pavement cannot be laid directly over the sub grade of $\mathrm{k}$ value less than $6 \mathrm{~kg} / \mathrm{cm} 2 / \mathrm{cm}$. Therefore, It has been proposed to provide dry lean concrete (DLC) of $100 \mathrm{~mm}$ thick as a base course for rigid pavement to increase „, $\mathrm{K}^{\mathrm{e}}$ value by $18.7 \mathrm{~kg} / \mathrm{cm} 2 / \mathrm{cm}$. It has been observed that rigid pavement with permeable sub base course like drainage layer gave very good performance with no faulting, cracking or joint spalling. In view of this observation, it has been proposed to introduce drainage layer of granular sub base (GSB-II) below DLC.

\section{Provision of Dowel Bar \& Tie Bar}

It will have doweled contraction joints at $4.0 \mathrm{~m}$ spacing. The longitudinal joints will have a spacing of $3.75 \mathrm{~m}$ and $3.50 \mathrm{~m}$ in order to accommodate $0.25 \mathrm{~m}$ wide edge strips. Expansion joints will be provided only at the junctions of structures like culverts, bridges etc. Based on volume of commercial vehicles following layer composition is proposed for concrete pavement. The concrete pavement composition is as follows:

Table: use of dowel and tie bars

\begin{tabular}{|c|c|c|c|c|c|c|c|c|}
\hline \multirow{2}{*}{$\begin{array}{c}\text { Traffic } \\
\text { MSA }\end{array}$} & \multirow{2}{*}{$\begin{array}{l}\text { Panel Size } \\
\text { (m) }\end{array}$} & \multicolumn{3}{|c|}{ Layer Composition } & \multicolumn{2}{|c|}{ Dowel Bar } & \multicolumn{2}{|c|}{ Tie Bar } \\
\hline & & PQC (mm) & DLC (mm) & GSB (mm) & Dia. (mm) & Spacing (mm) & Dia. (mm) & Spacing (mm) \\
\hline 53.8 & $3.5 \times 4.0$ & 300 & 100 & 150 & 32 & 300 & 12 & 500 \\
\hline
\end{tabular}

\section{Initial Construction Costing of Concrete Pavement}

Table: Initial Cost Details

\begin{tabular}{|c|c|c|c|c|c|c|}
\hline Layers & Cost $/ \mathrm{km}$ & No & Length (m) & Thickness (m) & Width (m) & Rate (Rs) \\
\hline Excavation & 762,300 & 1 & 1000 & 0.55 & 10.5 & 132.00 \\
\hline GSB-II & $1,889,339$ & 1 & 1000 & 0.15 & 10.5 & $1,199.58$ \\
\hline DLC & $3,597,773$ & 1 & 1000 & 0.1 & 10.5 & $3,426.45$ \\
\hline PQC & $16,893,450$ & 1 & 1000 & 0.3 & 10.5 & $5,363.00$ \\
\hline Initial Cost & $23,142,861$ & & & & & \\
\hline
\end{tabular}

\section{Design f Junctions}

In project road there are a number of minor junction and 6 major junctions. All minor junctions connect the collector roads to main carriageway and are designed according to
IRC standards. Improved facilities/parameters are proposed at major junctions and are tabulated below. The details of junction layouts are shown in the design plan.

Table: junctions observed along the road

\begin{tabular}{|c|c|c|c|c|c|}
\hline Sl. No. & Chainage & Type of Junction & Connecting Road & Treatment & Turning Radii Provided (m) \\
\hline 1 & $0+000$ & $\mathrm{~T}$ & GachibowliMiyapur & Unsignalized & $10-30$ \\
\hline 2 & $2+420$ & + & SaiPruthvi Enclave Colony & Unsignalized & $10-30$ \\
\hline 3 & $2+640$ & + & SaiPruthvi Enclave Colony & Unsignalized & $10-30$ \\
\hline 4 & $3+810$ & $\mathrm{~T}$ & Prof. C. R. Rao Road & Unsignalized & $10-30$ \\
\hline
\end{tabular}

Cost comparison between Flexible Pavement and Rigid Pavement

A cost comparison between the options of repairing/rehabilitating the existing flexible pavement against the option of providing a new cement concrete pavement was made. When upkeep of two pavement options over a life time of 30 years are compared, maintenance costs of cement concrete pavement are negligible compared to that of the flexible pavement. Nonetheless, in this case the initial 


\section{International Journal of Science and Research (IJSR) \\ ISSN (Online): 2319-7064 \\ Index Copernicus Value (2013): 6.14 | Impact Factor (2015): 6.391}

construction cost of the cement concrete pavement far offsets the benefits of providing a rigid pavement.

Considering the initial cost of construction, the time of opening to traffic and the client"s requirement flexible pavement is proposed for the project road

\section{Storm Water Drainage}

Storm water drains are available for very short length abutting Sarada Nagar and of closed type of width 0.40 $0.75 \mathrm{~m}$. Remaining length there is no proper surface drainage and majority of the length is in water logging condition during monsoon for lack of storm water drain.

\section{Rational Method for Flood Estimation}

The rational method is a universally accepted, empirical formula relating rainfall to runoff and is applicable to small catchment areas not exceeding $50 \mathrm{Km} 2$. The entire precipitation over drainage district does not reach the drain. The characteristics of drainage district such as imperviousness, topography including depressions and duration of precipitation etc, from which fraction of the precipitation which will reach to the drain has to be determined. This fraction is known as co-efficient of runoff which will be determined for each drainage district depending on its characteristic. The runoff reaching the drain is given by fhe expression

$\mathrm{Q}=0.028$ PAIC

Where:

$\mathrm{Q}=$ discharge (peak runoff) in cumec

$\mathrm{P}=$ coefficient of run-off for the catchment characteristics

A =area of catchment in hectares

Ic $=$ critical intensity of rainfall in $\mathrm{cm} / \mathrm{hr}$ for the selected

frequency and for duration equal to the time of concentration

\begin{tabular}{|c|c|c|}
\hline \multicolumn{3}{|c|}{ COST SUMMARY : BOTANICAL GARDEN ROAD } \\
\hline Section & Short Description & $\begin{array}{c}\text { Total Amount } \\
\text { (Rs.) }\end{array}$ \\
\hline 1$)$ & Site Clearance & 56690 \\
\hline 2$)$ & Earthwork & 18711757 \\
\hline 3) & $\begin{array}{c}\text { Drainage and Protective Works, Shabad } \\
\text { stone in FP, cross pipes for utilities etc }\end{array}$ & 56518479 \\
\hline 4$)$ & Pavement & 166694373 \\
\hline 5$)$ & Road Markings & 2507528 \\
\hline 6$)$ & Total & $24,44,88,827$ \\
\hline 7$)$ & Add vat @ 5\% & $1,22,24,441$ \\
\hline 8$)$ & Labour Charges @ 1\% & $24,44,888$ \\
\hline 9$)$ & QC Charges & $5,00,000$ \\
\hline 10$)$ & 1\% for shifting utilities & $24,44,888$ \\
\hline & Tender premium \& Price escalation \& & $1,28,96,956$ \\
\hline 11$)$ & Shifting \& electric lines & $\mathbf{2 7 , 5 0 , 0 0 , 0 0 0}$ \\
\hline & TOTAL (6-11) &
\end{tabular}

\section{Conclusion}

The stretch of Botanical Garden Road, Kothaguda in the scope of work starts from the Kothguda Junction of GachibowliMiyapur Road and ends at Prof. C.R. Rao Road Junction via Sri Ram Nagar, CMC and SaiPruthviEnclave.the design road for the project is 6 lane flexible pavement after estimating the different alternatives present. The project road is a major link in west Zone. The length of the project road is $3.85 \mathrm{~km}$. with a team of members we have successfully completed the widening and improvement of road project .by analysing and observing the road (i.ecracks,fissures, shoulders, foot paths, gutters, median etc. besides measuring available leeway for future expansion to accommodate future traffic.) through naked eye .traffic analysis is done at the site and results are plotted accuratelyand neatly by minimising the errors .and by collecting the undisturbed sample from site different test are performed in the lab to analyse the soil characteristics. and cost for different items of the work are calculated.

\section{References}

[1] Khanna S.K\& Justo C.E.G., "Highway Engineering" New Chand and Bros. Roorkee.

[2] Kadiyali L.R., "Traffic Engineering and Transport Planning" KhannaPublishers,New Delhi.

[3] Papa Costas C.S., "Transportation Planning and Design" PH Publications, New Delhi.

[4] Raghava constructions manual.

[5] Soil mechanics by ARORA.

[6] IRC: 37-2001,2012".guideline for flexible pavement design," government of India.

[7] environmental effects on flexible pavements wiki.com 